\title{
Wacana Pengampunan Pajak: Kajian Kohesi dan Koherensi
}

\author{
Sifandi $^{1^{*}}$, I Wayan Simpen ${ }^{2}$, Anak Agung Putu Putra ${ }^{3}$ \\ ${ }^{[123]}$ Program Studi Sastra Indonesia, Fakultas Ilmu Budaya, Universitas Udayana \\ [email: sifandi8@gmail.com], ${ }^{2}$ [email: wyn_simpen@unud.ac.id], \\ 3 [email:putraharini@yahoo.com] \\ *Corresponding Author
}

\begin{abstract}
Entitled with "The Discourse of Tax Amnesty: The Study of Cohesion and Coherence" this research purpose is to know the instrument of cohesion and coherence which built the discourse of the tax amnesty. The teory used is the discourse teory which are cohesion mentioned by Halliday and R. Hasan (in Dewi, 2010:20) and coherence mentioned by Kridalaksana (in Mulyana, 2005:32). The method used in data collection is scrutinize method which completed by technique note. In data analysis process used agih method which method use the language as the determiner helped by lesap technique and replacement technique afterwards. Furthermore, informal and formal method used as the presentation process of analysis data result. In informal presentation use common words, while the formal presentation use sign and symbol. The data source which used as the analysis materials with total of 62 articles comes up from Kompas. Com issued at February and March 2017. There are some revelation obtained based on the analysis in discourse of the tax amnesty. Firstly, in the discourse of the tax amnesty dicovered that the instrument of cohesion out from grammatical (references, substitution, ellipsis, and conjunction) as well as lexical (repetition, synonym, antonym, collocation, and equivalence). Secondly, the coherence elements in the discourse of the tax amnesty are the causality relationship, instrument goal relationship, conclusion background relationship, leniency results relationship, parafrastis relationship, amplicative relationship, time additive (simultaneous and in sequence) relationship, non-time additives relationship, identification relationship, and spesific generic relationship.
\end{abstract}

Keywords: discourse, cohesion, coherence

\begin{abstract}
Abstrak
Penelitian ini berjudul "Wacana Pengampunan Pajak: Kajian Kohesi dan Koherensi" dengan tujuan untuk mengetahui alat-alat kohesi dan unsur koherensi yang membangun wacana pengampunan pajak. Teori yang digunakan adalah teori wacana, yaitu kohesi yang dikemukakan oleh Halliday dan R. Hasan (dalam Dewi, 2010:20) serta koherensi yang dikemukakan oleh Kridalaksana (dalam Mulyana 2005:32). Metode yang digunakan dalam pengumpulan data adalah metode simak yang dilengkapi dengan teknik catat. Kemudian, dalam proses penganalisisan data digunakan metode agih, yakni justru alat penentunya adalah bahasa itu sendiri yang dibantu dengan teknik lesap dan teknik ganti. Selanjutnya, proses penyajian hasil penganalisisan data digunakan metode informal dan formal. Penyajian secara informal dilakukan dengan menggunakan katakata biasa, sedangkan penyajian formal dilakukan menggunakan tanda dan lambang. Sumber data yang dijadikan bahan analisis adalah teks berita pengampunan pajak di
\end{abstract}


media Kompas. Com yang terbit pada Februari dan Maret 2017 dengan jumlah keseluruhan 62 berita. Berdasarkan analisis yang telah dilakukan pada wacana pengampunan pajak ditemukan beberapa hal. Pertama, dalam wacana pengampunan pajak ditemukan adanya penggunaan alat-alat kohesi, baik dari segi gramatikal (berupa pengacuan/referensi, penggantian/substitusi, pelesapan/elipsis, dan perangkaian/ konjungsi) maupun segi leksikal (berupa pengulangan/repitisi, padan kata/sinonim, lawan kata/antonim, sanding kata/kolokasi, dan kesepadanan/ekuivalensi). Kedua, unsur koherensi dalam wacana pengampunan pajak meliputi hubungan sebab akibat, hubungan sarana hasil, hubungan alasan sebab, hubungan sarana tujuan, hubungan latar kesimpulan, hubungan kelonggaran hasil, hubungan syarat hasil, hubungan perbandingan, hubungan parafrastis, hubungan amplikatif, hubungan aditif waktu (simultan dan beruntun), hubungan aditif nonwaktu, hubungan identifikasi, dan hubungan generik spesifik.

Kata kunci: wacana, kohesi, koherensi

\section{Latar Belakang}

Satuan kebahasaan yang berada pada tataran tertinggi adalah wacana. Mulyana (2005:26) mengatakan bahwa wacana utuh dibangun oleh dua unsur, yaitu unsur kohesi dan unsur koherensi. Unsur kohesi meliputi aspek-aspek leksikal, gramatikal, fonologis, sedangkan unsur koherensi mencakup aspek semantik dan aspek topikalisasi.

Berdasarkan media penyampaiannya, wacana dibagi menjadi dua macam, yaitu wacana tulis dan wacana lisan. Salah satu bentuk wacana tulis di media massa adalah berita pengampunan pajak (tax amnesty) yang terbit di media Kompas. Com. Berita yang diterbitkan itu tidak hanya menginformasikan kepada pembaca tentang pengampunan pajak, tetapi juga memberikan imbauan dan arahan dalam mengikuti program tersebut. Selain itu, berita tersebut juga mengajak pembaca untuk mengikuti program pengampunan pajak yang sedang dilaksanakan oleh pemerintah. Semua informasi tersebut dikemas dalam satu berita. Keberhasilan program pemerintah juga didukung oleh berita yang disebarluaskan. Unsur bahasa yang digunakan tersebut menjadi daya tarik dalam penelitian ini, seperti penggunaan alat-alat kohesi dan unsur koherensi.

\section{Pokok Permasalahan}

Berdasarkan latar belakang di atas dapat dirumuskan masalah sebagai berikut.

a) Alat-alat kohesi apa sajakah yang terdapat dalam wacana pengampunan pajak?

b) Unsur koherensi apa sajakah yang membangun wacana pengampunan pajak?

\section{Tujuan Penelitian}

Berdasarkan rumusan masalah di atas dapat diuraikan tujuan penelitian seperti berikut ini.

a) Untuk mengetahui alat-alat kohesi yang terdapat dalam wacana pengampunan pajak.

b) Untuk mengetahui unsur koherensi yang membangun wacana pengampunan pajak.

\section{Metode Penelitian}

Sumber data penelitian yang digunakan adalah teks berita pengampunan pajak yang terbit di media Kompas. Com. Metode yang digunakan dalam pengumpulan data adalah metode simak yang dilengkapi dengan teknik catat. Kemudian, dalam proses penganalisisan data digunakan metode agih, yakni justru alat penentunya adalah bahasa itu sendiri 
yang dibantu dengan teknik lesap dan teknik ganti. Selanjutnya, hasil penganalisisan data disajikan melalui dua metode, yakni (1) metode informal adalah perumusan dengan kata-kata biasa dan (2) metode formal adalah perumusan dengan tanda-tanda atau lambanglambang.

\section{Hasil dan Pembahasan}

Pembahasan pada penelitian ini dilakukan dengan membagi data berdasarkan kohesi, baik segi gramatikal maupun segi leksikal, serta unsur koherensi yang terdapat pada wacana pengampunan pajak.

\subsection{Kohesi}

Teori yang digunakan untuk menganalisis kohesi, yaitu teori kohesi yang dikemukakan oleh Halliday dan R. Hasan.

\subsubsection{Kohesi Gramatikal}

\subsubsection{Pengacuan (Referensi)}

Pada pengacuan terdapat tiga bagian, yaitu (a) pengacuan persona (persona pertama, kedua, dan ketiga), pengacuan demonstratif, dan pengacuan komparatif. Contoh sebagai berikut. "Saya enggak tahu apakah Rp 29 triliun atau berapa". Unsur saya merupakan pronomina persona pertama tunggal bentuk bebas yang bersifat eksofora (acuannya berada di luar teks).

\subsubsection{Penggantian (Substitusi)}

Penggantian (substitusi) berkaitan dengan penggantian unsur tertentu dengan unsur yang lain yang mengacu pada realitas yang sama. Contoh sebagai berikut. "Direktur Jenderal Pajak Ken Dwijugiaseteadi memperlambat ritme bicaranya. Ia tiba-tiba mengaku sedih...". Unsur ia memiliki hubungan substitusi dengan unsur Direktur Jenderal Pajak Ken Dwijugiaseteadi karena unsur ia dapat digantikan dengan unsur Direktur Jenderal Pajak Ken Dwijugiaseteadi.

\subsubsection{Pelesapan (Elipsis)}

Pelesapan (elipsis) berkaitan dengan proses pelesapan satuan lingual tertentu yang telah disebutkan sebelumnya. Contoh sebagai berikut. "Dampaknya tidak signifikan, $\boldsymbol{\varnothing}$ akan biasa-biasa saja". Terdapat pelesapan satuan lingual berupa nomina yang tergolong ke dalam tataran kata. Unsur yang dimaksud adalah kata dampaknya yang berfungsi sebagai keterangan.

\subsubsection{Perangkaian (Konjungsi)}

Pada perangkaian terdapat berbagai macam makna, seperti menyatakan hubungan waktu, hubungan syarat, hubungan tujuan, hubungan perlawanan, hubungan pemilihan, hubungan konsesif, hubungan penyebaban, hubungam cara, hubungan penjumlahan, hubungan hasil, hubungan optatif, hubungan hasil, dan hubungan komplementasi. Contoh sebagai berikut. "Sejak pagi wajib pajak sudah menyerbu sejumlah kantor pajak untuk ikut program langka tersebut". Konjungsi sejak merupakan hubungan waktu permulaan dipakai untuk menggam-barkan sejumlah kantor pajak dari pagi diserbu wajib pajak yang mengikuti program tersebut.

\subsubsection{Kohesi Leksikal}

\subsubsection{Pengulangan (Repitisi)}

Pengulangan (repetisi) merupakan pengulangan leksem yang sama dalam sebuah wacana. Contoh sebagai berikut. "Kami akan melihat data bea cukai, perpajakan, sampai daerah akan kami lihat. Kami akan lakukan pelaksanaan undang-undang pajak secara konsisten". Unsur kami diulang sebanyak tiga kali yang berfungsi untuk menegaskan bahwa pihak pemerintah akan menindak tegas wajib pajak secara konsisten sesuai dengan undang-undang perpajakan. 


\subsubsection{Padan kata (Sinonim)}

Padan kata (sinonim) merupakan kata-kata yang mempunyai makna dengan bentuk yang berbeda. Contoh sebagai berikut. "Seperti diketahui, penghapusan pasal kerahasiaan perbankan itu untuk memenuhi syarat pertukaran informasi perbankan untuk kepentingan perpajakan atau Automatic Exchange of Information (AEoI) pada 2018... Termasuk menghilangkan pasal kerahasiaan bank yang ada di Undangundang Perbankan". Kata penghapusan dengan kata meng-hilangkan memiliki hubungan kemiripan makna yang mutlak.

\subsubsection{Lawan kata (Antonim)}

Lawan kata (antonim) merupakan kata-kata yang mempunyai arti berlawanan. Contoh sebagai berikut. "Bank Indonesia (BI) mencatat terjadi penurunan utang luar negeri (ULN) swasta pada kuartal IV 2016. Sementara itu, ULN publik mengalami peningkatan". Kata penurunan beroposisi dengan kata peningkatan yang memiliki hubungan oposisi yang mutlak.

\subsubsection{Sanding kata (Kolokasi)}

Sanding kata (kolokasi) merupakan pemakaian kata-kata yang berada di lingkungan yang sama. Contoh sebagai berikut. "Bahwa ada dukungan, ada protes, ada kritikan, itu biasa". Ketiga kata tersebut berkolokasi dalam hal kepemimpinan.

\subsubsection{Kesepadanan (Ekuivalensi)}

Kesepadana (ekuivalensi) merupakan penggunaan kata-kata yang memiliki kemiripin makna atau maknanya berbeda. "Program pengampunan pajak atau tax amnesty akan berakhir pada Jumat (31/3/2017) hari ini. Di hari terakhir tax amnesty ini...". Dua kata tersebut, yaitu kata berakhir dan terakhir terbentuk dari kata akhir.

\subsection{Koherensi}

Koherensi adalah hubungan semantis yang terjadi antarproposisi dan direpresentasikan dengan perpautan kalimat (bagian) yang satu dengan yang lain (Kridalaksana dalam Mulyana, 2009:32). Hubungan semantis yang dimaksud, yaitu hubungan sebab akibat, hubungan sarana hasil, hubungan alasan sebab, hubungan sarana tujuan, hubungan latar kesimpulan, hubungan kelonggaran hasil, hubungan syarat hasil, hubungan perbandingan, hubungan parafrastis, hubungan amplikatif, hubungan aditif waktu (simultan dan beruntun), hubungan aditif nonwaktu, hubungan identifikasi, hubungan generik spesifik, dan hubungan ibarat. Akan tetapi, hubungan ibarat tidak ditemukan. Berikut beberapa contoh hubungan semantis.

\subsubsection{Hubungan Sebab Akibat}

Hubungan ini dinyatakan dengan kalimat pertama sebagai sebab, sedangkan kalimat berikutnya sebagai akibat. Contoh sebagai berikut. "Kepala KPP Pratama Pulogadung Edward Hamonangan Sianipar memastikan, bila wajib pajak mampu menunjukkan COD maka akan terhindar dari pajak berganda. "Masalahnya, mereka (wajib pajak) selama ini belum pernah melaporkan penghasilan juga di sini. Dengan tax amnesty, di mana-mana deklarasi luar negeri, WNI di luar kena pajak, di Indonesia kena pajak juga jadinya". Wacana ini menunjukkan bahwa mereka (wajib pajak) selama ini belum pernah melaporkan penghasilannya di Indonesia yang mengakibatkan mereka di luar negeri juga terkena wajib pajak. Hal ini ditandai dengan unsur jadinya.

\subsubsection{Hubungan Sarana Hasil}

Hubungan ini dinyatakan dengan kalimat pertama merupakan sarana untuk perolehan kalimat berikutnya. Contoh sebagai berikut. "Menurut Sri Mulyani, 
Presiden Joko Widodo telah memberikan dukungan dan kepercayaan besar dalam menyukseskan program tax amnesty. Begitu pula dengan berbagai pihak lainnya. "Saya berterima kasih atas dukungan dan kepercayaan yang telah diberikan Presiden dan berbagai pihak dalam menyukseskan program tax amnesty. Kepercayaan tersebut adalah modal kuat untuk kami melayani masyarakat lebih baik lagi". Kepercayaan yang diberikan oleh presiden dan berbagai pihak dalam menyukseskan program tax amnesty adalah modal kuat untuk melayani masyarakat yang lebih baik lagi. Hal ini ditandai dengan unsur berterima kasih.

\subsubsection{Hubungan Alasan Sebab}

Hubungan ini dinyatakan dengan kalimat pertama merupakan alasan penyebab kalimat berikutnya. Contoh sebagai berikut. "Asosiasi Pengusaha Indonesia (Apindo) menilai pelaksanaan program tax amnesty belum sesuai harapan pengusaha. Sebab di dalam pelaksanaannya, masih ada sejumlah masalah teknis yang ditemukan. Hal itu diungkapkan Ketua Apindo Haryadi Sukamdani saat memberikan sambutan dalam acara Farewell Tax Amnesty. Acara itu dihadiri langsung oleh Presiden Jokowi. "Masih ada beberapa masalah teknis yang dapat menghambat optimalisasi amnesti pajak". Penilaian Asosiasi Pengusaha Indonesia (Apindo) terhadap pelaksanaan program tax amnesty tentang sejumlah teknis yang masih ditemukan merupakan hubungan sebab yang ditandai dengan unsur sebab.

\subsubsection{Hubungan Sarana Tujuan}

Hubungan ini dinyatakan dengan kalimat yang menyatakan syarat untuk mencapai tujuan yang dinyatakan pada kalimat lainnya. Contoh sebagai berikut. "Anggota Komisi XI DPR RI Mukhamad Misbakhun mendorong Bank Indonesia
(BI) dan Otoritas Jasa Keuangan (OJK) untuk membuka rahasia perbankan. Tujuannya adalah menggenjot penerimaan negara. Misbakhun mengatakan, realisasi penerimaan negara dari sektor perpajakan selama tiga tahun terakhir meleset dari target. "Secara penerimaan, sektor pajak terburuk. Secara persentase menurun". Wacana ini menunjukkan bahwa untuk menggenjot penerimaan negara, anggota Komisi XI DPR RI Mukhamad Misbakhun mendorong Bank Indonesia (BI) dan Otoritas Jasa Keuangan (OJK) membuka rahasia perbankan. Hal ini ditandai dengan unsur tujuannya.

\subsubsection{Hubungan Latar Kesimpulan}

Hubungan ini dinyatakan dengan salah satu kalimat yang merupakan simpulan atas pernyataan pada kalimat lainnya. Contoh sebagai berikut. "Ia menambahkan, program pengampunan pajak merupakan salah satu kebijakan khusus yang dibuat pemerintah bagi mereka yang belum taat administrasi. Namun, kata Wapres, bila dalam pelaksanaannya hanya sedikit wajib pajak yang mengikuti tax amnesty artinya ada nilai positif yang bisa diambil. "Kalau tidak banyak (yang ikut) tax amnesty, berarti tidak banyak juga orang yang salah". Wajib pajak yang mengikuti tax amnesty hanya sedikit berarti tidak banyak orang yang salah. Hal ini ditandai dengan unsur kalau dan unsur berarti.

\subsubsection{Hubungan Aditif Nonwaktu}

Hubungan ini dinyatakan dengan gagasan pada kalimat pertama diikuti atau ditambah dengan gagasan pada kalimat berikutnya. Contoh sebagai berikut. "Secara penerimaan, sektor pajak terburuk. Secara persentase menurun". Wacana ini menunjukkan bahwa secara bersamaan penerimaan negara dari sektor perpajakan mengalami pemburukan dan penurunan. 


\section{Simpulan}

Berdasarkan hasil analisis wacana pengampunan pajak diperoleh dua simpulan. Pertama, alat-alat kohesi yang ditemukan, yakni kohesi gramatikal (berupa referensi, substitusi, elipsis, dan konjungsi) dan kohesi leksikal (berupa repitisi, sinonim, antonim, kolokasi, dan ekuivalensi). Kedua, unsur koherensi dalam wacana pengampunan pajak meliputi hubungan sebab akibat, hubungan sarana hasil, hubungan alasan sebab, hubungan sarana tujuan, hubungan latar kesimpulan, dan hubungan aditif nonwaktu.

\section{Daftar Pustaka}

Dewi, Ketut Eva Cintya. 2010. "Wacana Iklan Komersial Berbahasa Indonesia di Televisi Swasta". Skripsi Jurusan Sastra Indonesia Fakultas Sastra Universitas Udayana, Denpasar.

Halliday, M.A.K. dan Ruqaiya Hasan. 1976. Cohesion in English. London: Longman.

Mulyana. 2005. Kajian Wacana, Teori, Metode, dan Aplikasi PrinsipPrinsip Analisis Wacana. Yogyakarta: Tiara Wacana. 